\title{
Analysis of the Relationship between the First Pahlavi's Authoritarian Modernization Discourse and the Islamist Discourse in Iran
}

\author{
Ali Bagheri Dolatabadi \\ Assistant Professor, Department of Political Sciences, Yasouj University, Iran \\ abagheri@yu.ac.ir
}

\begin{abstract}
The seminary (Howza), as the representative of religion, and the state, as the representative of politics, has brought about different patterns of the convergence-divergence relationship in Iran's history. In this regard, the relationship of the first Pahlavi king (Reza Shah) and the Seminary is of special ambiguity and complexity which is the subject of this paper. The question posed in this respect is: "What components have been effective in the relationship of the Qom Seminary ${ }^{l}$ and the State in the years between 1921 and 1941?" This paper focuses on the hypothesis that from the beginning of the political life of Reza Shah to1930, due to lack of cohesion and institutional power of the central government, the two institutions of the State and the Seminary had an interactive relationship for the establishment of order and security in the society; however, after the centralization and consolidation of the power of Reza Shah, competition and antagonism replaced interaction and convergence. The findings of the paper that are obtained in the descriptive-analytic method and by means of the discourse analysis theory of Laclau and Mouffe, show that the emergence of the two discourses of archaism and Islamism has been the result of this competition and antagonism.
\end{abstract}

Keywords: Reza Shah Pahlavi, the Seminary (Howza), discourse, Islamism, Modernisation

\section{INTRODUCTION}

After the failure of the Constitution ${ }^{2}$ and disintegration of the social and political order of Iran in the last decade of the Qajar dynasty, none of the political movements had the power to regulate the society and politics. The competition and antagonism between the Constitutionalists, the Legitimists and the Monarchists had caused political concepts to lose their meanings to validate order and security among people. Therefore, an unknown, unfamiliar and new movement was needed that could serve common interests for establishment of order. This movement was the emerging authoritarian modernization or enlightened despotism (or absolutism) discourse. It can be therefore noted that Reza Shah, by the endorsement and accompaniment of the foreign forces and supplication of some domestic movements, entered the country's political arena by the coup d'etat of 22 February 1921 in Tehran. Reza Shah's coup d'etatentertained thehope that a new era has started in Iran's political-social life since he had managed to attract the support of a broad range of tradition alist and modernist forces. In fact, in his political agenda, Reza Shah at once played the role of a king among the traditionalist forces, the role of a military for establishment of order and the role of a modernist for modernization of Iran; thus, it was upheld by the three Monarchist, Legitimist and Constitutionalist political movements.

Although the political movements' support of Reza Shah is justifiable through the Iranian society's need for order, the maintenance of this relation is quite unknown and although numerous studies have

\footnotetext{
${ }^{1}$ Qom Seminary (Qom Hawza) is largest Hawza (seminary of traditional Islamic school of higher learning) established in 1922 by Grand Ayatollah Abdul-KarimHa'eriYazdi in Qom.
}

${ }^{2}$ Mashruteh-ye Iran which is the Iranian Constitutional Revolution or shortly, the Constitution. 
been so far conducted in this area, few studies have managed to delve into the real reasons behind it since Reza Shah's political behavior, from the 1921 coup d'etatuntil 1930 when he officially declared his archaism, has been such that it parted with the two Legitimist or Islamist and Constitutionalist or Nationalist movements. Meanwhile, Reza Shah's relationship with the Islamist movement is more ambiguous than his relationship with the Constitutionalists; since although, on the surface, Reza Shah seems to have been against Islam from the beginning to the end of his government, if we reflect on Reza Shah's relationship with Islam, we will realize that throughout his government, there has been no conflict and antagonism between these two movements and that, rather, it has traversed a trajectory of interaction to antagonism. In order to prove this claim, it is necessary that the extent and scope of this paper be determined by addressing the relevant questions so that by answering them, the results could be proved. The first question posed in this regard is "to what extent have the studies conducted in this regard managed to clarify its ambiguous points and what aspects have they failed to elucidate?" The second question is "how much is the discourse theory effective in investigating this issue?" The third question is "what are the competing discourses from the emergence to the consolidation of the enlightened despotism discourse?" The fourth question is "what has been the relationship between the Islamist and the enlightened despotism discourses from the beginning to the end of the downfall?"

\subsection{Literature Review}

Abu al-HasanShirazi[1], in the book "Political and Social Developments of Iran in the Qajar Period and the Rise of Reza Shah", has attempted to look into the reasons for the emergence of the enlightened despotism discourse. This book's emphasis on the social and political factors in the emergence of the Pahlavi government indicates that structuralism is dominant in this book and that the role of Reza Shah in the formation of the Pahlavi government has been less highlighted than that of political and social movements. DariushRahmanian[2], in the book "The Challenge of the Republic and Monarchism in Iran", considers Reza Shah as the winner of the competition between the two Democratic and Monarchist movements. This book, through its agency-structure debate, does not consider the Islamist movement to be involved in the support of and competition with the Republic and Reza Khan. In his book, Rahmanian has given more importance to the political crisis than the social factors. Davoud Amini, in the book "The Challenge of the Clergy and Reza Shah", has instead emphasized the substantial role for the clergy inthe opposition with his monarchy. Rahmani has, for instance, stressed out the role of the Majlis ${ }^{3}$ and the leadership of Modarresin prevention from his rise to power and consolidation of power. This book has not strongly emphasized the role of the political and social structures in Reza Shah's rise to power and concentrates on the role of Reza Shah and Modarres.

Qolam'aliRajayi[3], in the book "Islamophobia of Reza Shah", has tried to prove this claim that Reza Shah acted against Islam and the clergy. By enumerating some of Reza Shah's anti-traditionalist behaviors, this book has attributed these measures to his Islamophobia. In this book, the agencystructure debate has not been mentioned. Ibrahim Safaei[4], in the book "National Foundations in Reza Shah's Monarchy", has attempted to link the ideals of the Constitutionalists in formulating a national identity to Reza Shah's authoritarian nationalism. The author, in this book, has tried to prove that Reza Shah's monarchy had been a national demand. This book, by emphasizing the importance of nationalist structures, has highlighted Reza Shah's role as the agent of these structures. Also, Mohammadjavad Nowruzi[5], in the paper "The Challenge of Religion and Secularism in the Era of Reza Shah", has investigated this important issue that the relationship of the clergy and religion with Reza Shah had been, from the very beginning, based on antagonism and conflict. The author of this paper has extended this relationship to the totality of the Pahlavi government and has considered religion as a traditionalist matter and Reza Shah as the supporter of secularism. In fact, this paper intends to demonstrate that, according to Reza Shah, there has been an innate divergence and conflict between religion and modernity.

In summing up the literature review, it could be stated that many studies have concerned the relationship between religion and Pahlavi government or the political and social structures and Reza Shah's rise to power; yet the dominant criticism regarding all of them is that most of these studies show a kind of opposition and hostility between the society and the State, without taking this point

${ }^{3}$ The Majlis or the Islamic Consultative Assembly of Iran (also called The Iranian Parliament or People's House) is the national legislative body of Iran. 
into account that political and social developments are discursive affairs that can't be proved by investigating a single factor. For this reason, the present study, by drawing on the discourse analysis theory of Laclau and Mouffe, intends to analyze the relationship between religion and the State in Reza Shah's era from a multi-factorial perspective.

\subsubsection{Discourse; Mediator between the Political and the Social}

The word "discourse" which, in some resources, dates to the $14^{\text {th }}$ century, derives from the French word discours [dis-koor] and the Latin word discurs-us meaning dialogue, conversation, speech and the word discursum and discurrer meaning to dodge, to evade, to delay, etc. [6]. Discourse, as a technical term, was primarily used in linguistics by Zellig Harris, and since then, the discourse analysis in linguistics has been through different stages[7]. It should be noted that in linguistics, the role of power and ideology in discourse has been less emphasized. Use of discourse for investigation of power and its relations goes back to Michel Foucault's studies in his methodology of genealogy and archaeology. From the analytical perspective, the concept of discourse has been inspired by three epistemological principles that have greatly influenced its conceptual dimensions and aspects. These are: 1-The meta narratives of Jean-François Lyotard[8], 2-Anti-foundationalism by Richard Rorty: and 3-Anti-essentialism by Jacques Derrida[9]. In this regard, it can be said that discourse is an interdisciplinary analysis tool which studies the communication fields between various scientific fields from sociology and history to linguistics and literature. Discourse analysis is in fact an effective tool for social and human studies.

Based on discourse analysis, two types of discourse change and development are conceivable and possible. Change in the discourse and change from the discourse. Change from the discourse refers to comprehensive and substantive fundamental transformation and metamorphosis which occurs due to changes made in the principles dominant in a discourse. In other words, if the core and fundamental principles of a discourse are altered or abolished, change from the discourse will take place. Change in the discourse also takes place when the discourse is stabilized and it pursues the efforts to achieve its ideals. Due to lack of proper conditions, in most cases this effort fails and the discourse has to limit the meaning of its signs. This is when change in the discourse occurs and inter-discourse antagonism begins [10]. Among the theories considered regarding change in the discourse and change from the discourse, the theory of Laclau and Mouffe is of more value and efficiency since this theory looks into social and political relations for the emergence and change of discourse. For investigation of research issues by means of the discourse tools of Laclau and Mouffe, its concepts must be defined so that generalization which is nevertheless accompanied by ambiguity could be prevented.

\subsection{The Concepts of Discourse}

\subsubsection{Antagonism}

The first concept which can be reflected in the discourse analysis theory is the presence of tension in political and social relations. Tension is the cause of conflict and antagonism for establishment of order or disruption of the dominant order. In fact, tension is the prerequisite for discourse. Without tension, the discourse loses its identity and meaning since according to Foucault, authority of parents over children, authority of the science of medicine over the population, authority of psychology over psychiatric patients and the like are considered as examples of struggles which are not aimed at attacking a certain group but attacking a method of power.

Tension is the cause of the main conflicts in the social and political arena. Tension is the attempt to determine the meaning and sense of belonging of a concept to a discourse or redefinition of a concept. As the relations between people are full of the struggle for provision of meaning, identical meanings try to produce discourse. The discourse-making derived from tension is aimed at the attempt for hegemonization of the considered order. For instance, the tension that occurred in the last decade of the Qajar government paved the way for the emergence of discourses such as Islamism, enlightened despotism and nationalism in Iran. The attempt for discourse-making is actualized through articulation. 


\subsubsection{Articulation}

Articulation is the second concept in the theory of Laclau and Mouffe which is of high importance. Articulation "is an act which establishes a relationship between the dispersed elements, in the ideals of a discourse, so that the identity and meaning of the mentioned elements is amended and adjusted." The result of the totality and product of the articulation act is called "discourse" as in the enlightened despotism discourse which, by giving a political meaning to signs such as nation, Iran, law, Constitution, Islam, shah and modernity after the 1921 coup d'etat, tried to introduce itself to people as a real and practical discourse which has the required efficiency for establishment of order and security.

\subsubsection{The Field of Discursivity}

Tension and articulation take place in an area called the field of discursivity. "The field of discursivity is where the possible and potential meanings of the signs of different discourses have a floating presence. These meanings are outside the articulation of every discourse. The signifiers of the field of discursivity are like empty receptacles ready to receive any kinds of potential meanings. Selection of a meaning leads to the exclusion of other meanings and paves the way for new articulations in the formation of new discourses"[11]. The field of discursivity which led to the emergence of various discourses in Iran in 1921 was the socio-political environment of Iran in which various signifiers and signs were present and did not evoke a specific meaning for everyone. These signs challenged and rejected any meanings in the receptacle of the mind and language of Iranian people. For instance, the signifier of the Constitution which was indicative of the rule of law had taken on the meanings of "theft" and "looting" toward the end of the Qajar period, so much so that people would say "the Constitution has won"[12].

\subsubsection{Dislocation}

Dislocation refers to the events that are the results of the growth of hostility, antagonism and pluralism in the society. These events can't be symbolized by the existing discourse order. Thus, they try to disrupt it. Dislocation tends to disintegrate the existing discourse and has a bilateral impact: it threatens the existing identities; it creates an infrastructure for formation of new identities [13]. The dislocation of Iran at the end of the Qajar period stems from the struggles and competition of various political movements for de-signification of the Qajar discourse. In fact, the Legitimists, the Constitutionalists, the Nationalists and others, by competing against the Qajar government, helped destroy its credibility in the eyes of people, and strived to establish an Islamic or modern or authoritarian order.

\subsubsection{Closure}

Closure refers to the temporary pause and cessation of instability in identity-formation for the signs and temporary stabilization of a meaning for a sign in a discourse. Every discourse tries to absorb floating elements and signifiers through the reduction of multiplicity of meanings and its conversion into a completely stabilized discourse meaning. Once it manages to do so, the floating state is destroyed and a kind of closure occurs in the meaning of the mentioned sign and signifier which prevents from semantic oscillations but this closure is not permanent [14]. The coup d'etat of 22 February 1921 and Reza Khan's rise to power led to the temporary stabilization of the authoritarian monarchy discourse. Over five years, Reza Khan managed to change from a military commander into a king and temporarily introduce himself and his discourse to the Iranian people for the two subsequent decades.

\subsubsection{Hegemony}

An identity which is given to social agents in a discourse is achieved only by articulation within the hegemonic classification. Hegemonic behavior is an example of political behavior and includes the association of various identities of the political forces with a common project and establishment of social order and is considered among dispersed and diverse elements [15]. The purpose of hegemonic practices is the establishment or stabilization of the knowledge system and semantic network and hegemonic classification. These classifications are organized around the nodal point. The hegemonic practice has two basic conditions: presence of antagonistic forces and instability of boundaries of difference. The hegemonization of a discourse refers to its success in the stabilization of its concerned meanings. The coronation of Reza Shah and his plans for ordering the social and political arena in 
Iran show the hegemonization process of the enlightened despotism discourse. After stabilization, by establishing the administrative, judicial, educational, political and cultural system, this discourse tried to define its previous allies as enemies, and was nevertheless partially successful in this regard until August 1942. After his rise to power, Reza Shah simultaneously rejected the two Constitutionalist and Legitimist or Islamist discourses and turned into the sole discourse in the political arena of Iran, so much so that in August 1942 it was also the only discourse opposing the Allies and the domestic opposition forces.

\subsection{Reza Shah and the Existing Discourses in the Political Arena of Iran (1921 -1926)}

The study of the existing discourses toward the end of the Qajar government and the rise to power of the Pahlavi government are possible through the study of the history of that era. At this point in time, i.e. from the victory of the Constitutionalists over Mohammad Ali Shah to Reza Khan's coupd'et at of 22 February 1921, various sub-discourses had subjected the whole country of Iran to anarchy and insecurity. In the north-west, Sheikh Mohammad Khiabani had attempted to form a government. In the north-east, Colonel Mohammad Taqi Khan Pasian had disobeyed the central government and had then tried to establish an independent government against the Russian Bolsheviks. The stability in the north of the country was undermined by the uprising of MirzaKuchak Khan Jangali and withdrawal of Russian troops. In the south-west, Sheikh Khaz'alwas so determined about independence that he did not allow the envoys of Ahmad Shah into his court. The east and the south-east were so detached that they were not in touch with the central government. The situation of order and security in the country was undermined and the danger of disintegration was threatening Iran [16]. In the center, the young Ahmad Shah, in fear of the influential figures and governments, opted for new consecutive prime ministers. Modarres and Nizam al-SaltanahMafihad formed a national government in Kermanshah. The ending to this historical moment when the country had collapsed into anarchy, was the coup d'etat of 22 February 1921 [17].

The political commander of this coup d'etat was SeyyedZia'eddinTabatabaee, the managing director of the newspaper Ra'd (Thunder) and its military leader was Reza Khan Savad Kouhi. In fact, the 1921 coup d'etat was the starting point for the rise of a nationalist, Islamist and monarchist discourse that would serve the purpose of all parties. Seyyed Zia and Reza Khan, in the years between 1921 and 1926, took measures that served the ideals of all political movements. In this era, Reza Shah specifically, as the nodal point of the nationalism and authoritarian modernization discourses, tried to put down the local riots all over Iran (in the four corners), by adopting the views of all central political movements [18]. The last riots led to the defeat of ShaikhKhaz'alin 1925. Reza Shah, by the accompaniment of various political forces and movements, in the years between1921 and 1926, restored order and security all over Iran. He tried to win the support of the Constitutionalists by admitting the Majlis bills. In Ashurarituals, he covered his head in mud (as a common sign of mourning) and on the order of Ahmad Shah, he rose from a commander of the army in to a prime minister. In fact, the trajectory of the development of the personality of Reza Khan Mirpanj over five years and his change into Reza Shah was the dream of the three existing discourses in the political arena of Iran. The Constitutionalist discourse which looked for a powerful king that would respect the laws of the two Majlises, accompanied him. This discourse, led by figures such as Mohammad Ali Foruqi, Ali Akbar Davar, SardarAs'adBakhtiari and TeymourTash, upheld the monarchy and hegemony of the discourse of Reza Shah over Iran.

The second discourse was the Qajar dynasty which accompanied and supported him from his time as the commander of the army and also the prime minister to the Majlis Moasesan and establishment of the Pahlavi government. After coronation and after Ahmad Shah did not return to Iran, this discourse come to an end but it assigned the monarchist structures to Reza Shah. In fact, the monarchist discourse, by changing its political subjects from Qajar to Pahlavi, engaged in its re-reading. The third discourse was the Islamist discourse. The Islamist discourse responded to the measures of Reza Khan and later Reza Shah in two movements. In the beginning of Reza Khan's rise to power, the Najaf scholars and Haj Sheikh Abdul Karim HayeriYazdi accompanied him for establishment of order and religious rituals. The Najaf marja's even considered Reza Khan as the cause of expropriation of England. This accompaniment and support continued until the kashfehejab (the unveiling) event. The second movement of the Islamist discourse was led by Modarres who, accompanied by the nationalist Mosaddeq, had a rather realistic knowledge of Reza Khan and strived for achievement of the ideals of 
the Constitution. Thus, they accompanied Reza Khan in the slightest cases. By a study of the sociopolitical events of Iran in the years between 1921 and 1926, it becomes clear that the existing subdiscourses in the political arena of Iran had no opposition with the rise to power of the monarchist discourse of Reza Shah which was aimed at authoritarian modernization. Rather, the conflicts started after the coronation of Reza Shah and his measures with regard to modernization and renovation.

\subsection{Islamism and Archaism from Interaction toAntagonism}

\subsubsection{The Priority of the Discourse Order and Ideals or the Convergence Politics}

In the year 1922, two important events took place for the Shiite history in Iran: first, Reza Khan, the commander of the army, assumed power by coup d'etat and brought about the first Pahlavi discourse which started with the coup d'etat of 22 February 1921 and lasted until 1930, primarily by adapting an appeasing approach toward the Qom Seminary. Secondly, Ayatollah Abdul KarimHayeriYazdi moved from Arak to Qom and enhanced the Islamist discourse which had been previously formed by the constitutional scholars. At this point in history, both of these aforementioned figures, namely, Ayatollah Abdul Karim Hayeri and Reza Khan, the commander of the army and the king-to-be, consciously engaged in "religious affairs" and "policy-making" respectively. AfterAbdul KarimHayeri's arrival in Qom, the Islamist discourse moved toward more unity and order. Owing to Hayeri's practices, the undeveloped city of Qom turned into a great center for the education of mojtaheds and a gathering place for the first-rate marja`s and one of the biggest centers of religious politics in Iran. The empowerment of the Qom Seminary drew the unprecedented attention of the political system of Reza Shah's time. For this reason, Reza Shah who considered the power of his discourse to be on par with the Islamist discourse, did not stand opposed to the power of the Qom Seminary until his full rise to power. This policy of Reza Shah helped him in the implementation of his massive reform programs [19].

\section{A: Admission of Exiled Scholars from Iraq and Power Production/ Discourse Knowledge}

Any discourse, in order to become legitimate among people, must have underlying knowledge that is popular among people [20]. Thus, Reza Khan's discourse, in order to legitimate its power among people, welcomed the arrival of the Najaf scholars in Iran. The prime ministry era of the commander of the army was concomitant with the exile of some of the Najaf scholars to Iran and their residence in Qom. In fact, a large part of the success of the discourse of Reza Shah goes back to the events in Iraq and the attitudes of the Iranian scholars residing in the Shiite shrines. After the great efforts of the scholars of Iraq in the independence struggles of this country and the policy of England's government for domination of Malik Faisal in Iraq, which was conducted by a contract signed with him, Iranian scholars did not authorize it and demanded the exit of English troops from Iraq. The Iraqi government exiled two of the scholars ${ }^{4}$. Subsequently, the influential Iranian scholars residing in Qom and Karbala entered Iran as a protest. In a telegraph that Reza Khan, the minister of war, sent to the emigrant scholars and maraje', he welcomed their entry to Kermanshah. He wrote to them thus: "I have hereby also strongly ordered the western troop emir, who will meet with you within these two days, not to overlook your demands".

\section{B-Ideal formation based on background mythologies or the apparent dependence of Reza Khan on Religious Rituals}

According to Laclau and Mouffe, in order to succeed, a discourse must be able to harmonize its ideals with background mythologies in which people believe and propagate its ideals based on them. (In the same place) the pre-royal era, Reza Khan goes to any lengths to show respect to religious rituals. Malek Al-ShoaraBahar writes, in the book "political parties of Iran": "On the tenth of Muharram 1962 corresponding to August1922: the mourning group of the Gazzaghs entered the market with a special committee and order and special formulations... and the Cops Commander also, while he had uncovered his head and was throwing straw on his head, was seen at the front of the group. The other Qazzaq officers were also engaged in mourning behind Moshar Alay. Furthermore, on the eleventh night of the Muharram, the Qazzaqkhaneh group entered the market, had feasted for Sham-e Gariban and the Corps Commanfer, by bare head and legs, carried a candle and they went to Masjid-e Jame in

${ }^{4}$ Sheikh Mohammad Khalesizadh\&Seyyed Mohammad Sadr 
Tehran and Masjed-e Sheikh Abd Al-Hussain that were among the biggest elegy sessions and they circulated the Majlis for a round"[21]. This practice of Reza Khan at that time was the construction of Shiite ideals for revealing itself as legitimate with regard to the mythologies of the Muslim people. It seems that from a political perspective, for Reza Khan, drawing the approval of the clergymen in the seminary and the masses and respect to religious rituals by the monarch at the time of the weakness of the Qajar period, whether the monarch does so sincerely or pretends to be so, has been an issue of great importance.

\section{C-Accompaniment of the master signifier of the clergy and the nodal point of the king in the authoritarian despotic discourse}

The master signifier is a signifier that enhances or denies the relationship between the nodal point and the articulated signs of the discourse. The role of the master signifier is the legitimization of the power of the nodal point among people [22]. From 1921 until 1835 (i.e. from the coup year until the unveiling) Mr. Hayeri was the nodal point of the discourse of Islamism and also the master signifier of the authoritarian discourse of modernization. Hayeri inside Iran was "the first-rate political mojtahed" in the first era of the government of Reza Shah and due to the strong structure of the power of discourse of Islamism and due to the coalition strategy of Reza Shah, the relations between the scholars, and the king and the state became so great that if the state prevented from the programs and measures of some of the clergymen, the other scholars would overlook this or just express a slight protest and complaint. For instance, the riot of Isfahan under the leadership of Haj Aga Nourallah, scorn of Ayatollah Bafghi and his exile and eventually the detention and exile of SeyyedHasanModarres were three examples in this regard. Haj AqaNurallah that was the famous mojtahed of Isfahan at that time and the brother of Mr. Najefi, rose to the help of people. He went to Qom with some people and another group of scholars and people of Isfahan and resided there. $\mathrm{He}$ claimed that "this bullying king (Reza Shah) is not of any use to us, since he is a heretic" [23]. He asked all the scholars to join them but Ayatollah Hayeri's behavior was unbiased. "Although from the beginning to the end of the cessation of the emigrant scholars of Isfahan and other cities to Qom, the late Ayatollah Hayeri did not deviate from his neutral methods and did not negate or prove anything in this regard and didn't say or write about this, yet he commemorated the scholars in practice....”[24]. In the beginning years of formation of the Pahlavi state, as there existed a rather positive view toward religion, the same view led to the lack of emergence of this problem among these two institutions. With the development of the seminary in Qom and the presence of more students and scholars who entered this field and the official organization that was conducted by Sheikh Abdul Karim Hayeri which was of highly popular among people and the seminary people, the public opposition of the state with this charismatic figure or the master signifier of the discourse of Islamism was against the interests of the state.

The type of relationship between the scholars and Reza Shah from the beginning of his rise until the unveiling event is the period of interaction and convergence between the two discourses of Islamism and modernity of Reza Shah. In this historical period which was about 15 years, the two discourses contributed to each other in production and legitimization. Each used the other for idealization of its discourse among people and Reza Shah, by referring his legal needs in the field of politics to his master signifier which is Ayatollah Hayeri, tried to keep the relationship between religion and politics in a good state. Although in some cases such as control of the educational system by the state, establishment of the judicial system and the expropriation of the clergy from the judgmental system of the country and also the establishment of the divansalari system, this relationship went through periodic breakdowns, but nevertheless continued until the unveiling event. It was in the unveiling event that the clergy subordinate to the discourse of Islamism evidently rose against the state and Ayatollah Hayeri supported them. It was a support that cut the relationship between the state and Sharia and opposed the two discourses.

\subsubsection{The Period of Opposition with the Islamist Discourse}

The bordering and analysis is a permanent issue in the emergence and behavior of discourses. Bordering is a factor that distinguishes the familiar from the unfamiliar and proposes the tension and antagonism between the two discourses. Bordering is the cause of inter-discourse changes [25]. As mentioned earlier, at the time of their emergence, in order to benefit from the meeting and 
accompaniment of everyone, discourses set forth general ideals in order to make all the groups agree with them; but what leads to the failure of this policy is the lack of reading or accompaniment of the reality with the ideals or myths. Myths are previous issues and the efforts for their accompaniment with the truth or ideals lead to the emergence of antagonism. The efforts of Reza Khan for modernization of the traditional and Muslim Iranian society with the cultural and material manifestations of the modernity is an example of the failure of the ideals in the competition between reality and mythology.

After coronation, Reza Shah who strengthened the pillars of his government slowly attempted to expand the concepts and functions of modernity in the Iranian society. Thus, he started the first clashes with the discourse of Islamism. The modernization measures of Reza Shah were in such a way that, according to the scholars of the contemporary history of Iran, his attempt was considered as the opposition with and expulsion of the clergy from the arena of the society and politics. Yet this behavior was a discourse which was aligned with the essence of the authoritarian despotic contract. Reza Shah had used Islam for rising to power but he had not guaranteed that his modernization measures would be aligned with the demands of the clergy. Thus, his behavior led to the emergence of tension and bordering between the discourse of Islamism and modernization. Among his measures, the following can be mentioned.

\section{A-Determining the Teaching Plan of the Religious Sciences or Involvement in the Arena of Discourse}

After discourses are stabilized, they need to expand their borders. Thus expansion of borders leads to the emergence of antagonism between accompanying discourses. One of the discourse involvements of Reza Shah was the determination of the religious sciences teaching program of the seminaries in 1932. Teaching which was conducted by then based on old traditions, was now determined by the state and it was determined that the state intends to make many gradual changes in the religious students' educational programs and to harmonize and align all its special programs with these changes. The purpose of Reza Shah in this program was a kind of matching between the religious studies and the official education in the country. This effort was the first involvement that was soon reacted by the seminary [26].

\section{B-Expansion of Discourse Borders and Limitation of the Sharia Courts}

Another performance of the discourses that is the factor of inter-discourse tension is the expansion of the discourse borders to the previous structures. Structures that define that principle of discourses will never tolerate the competitors and tend toward reactions. For instance, in Azar 1310, new limitations were considered for sharia courts and it was determined that only state courts and the Attorney General can refer an issue to the sharia court and these references were limited to marriage, divorce and selection of trustees or trustee and guardian for orphans and widows and the wards. In addition to this, in February1932, in addition to the reform of the law of registration of documents for consideration of the complaints related to attorneys, certificates and registration of property transfers were eliminated from the tasks of the sharia courts and were relegated to courts of justice and therefore sharia courts were practically cancelled out [27]. The replacement of sharia courts with official state courts was an extensive involvement in the area of tasks that were present, in the form of religious structures, over fourteen centuries in Iran. This involvement of Reza Shah led to the unemployment of an extensive group of clergymen who in turn reacted to this.

\section{C-Legislation against the Judgment of Religious Scholars}

Legislation is the most important discourse behavior and practice which takes place after stabilization. The purpose of discourse for legislation is the ordering and establishing of modern structures against the previous laws and structures. One of the legislations of Reza Shah that led to the reaction of the discourse of Islamism was that in December 1935 a law was legislated which made the religious scholars' rise to judgmental careers very difficult or impossible. In this law, it was written: "The judge in the court of law must hold a BA degree-DaneshNameh-from the law faculty of Tehran or foreign schools, the current judges in the courts that do not have a BA, must pass a special exam in the Department of Justice" [28]. This limitation and legislation caused the discourse of Islamism to 
oppose Reza Shah in the society. The clergy also, by declaring the official state courts as illegitimate, created this gradation that the adequacy of the courts is not acceptable in terms of Sharia.

\section{D-Social Order and Discourse; Determination of the Regulations Related to Marriage}

Among the other functions of the discourse is the definition of the society. According to Laclau, a preexisting society does not exist. Rather, a society is constructed by discourses [29]. The authoritarian discourse of modernization of Reza Shah attempted to restore the modern Iranian society again and from its own perspective. One of such cases of restoration of the society was interference in marriage which builds the basis of the society. Thus, in April 11, 1932, the law of marriage was legislated in Majlis and in that it was written: "In the cases that Justice determines and declares, every marriage, divorce and reference must take place and be registered in one of the offices that were regulated according to the system of programs of the justice ministry. Therefore, the tasks of marriage and divorce exited the monopoly of religious scholars"[30]. The involvement of the state in the legitimization of marriage limited one of the other fields of social involvement of the clergy.

\section{E-Expansion of the Inclusion of Discourse Laws and the Management Style of Religious Affairs}

As mentioned earlier, in order to actualize their ideals, discourses need to objectify their laws. In such cases, the opposition between mythology and reality is established. Endowments which was in Iran, after Islam, the most important area of financial and job independence for the clergy or the discourse of Islamism, was exposed to reform at the time of Reza Shah and the management of Endowments was determined by the state. Moqufat was greatly developed in the Safavid era and after the assault of the Afghans and at the time of Nader Shah and Zandieh, became gradually low and out of order but in the Qajar era, people were again interested in the vaghf of their property for development of Shiite religion affairs and the management of most dedicated property was taken on by religious scholars. In December24, 1313, based on a bill that was legislated in Majlis, a department of state, under the supervision of the ministry of ma'aref, was formed for Endowments and its organization and management were ordered. The scholars objected. The Directorate of Religious Affairs was important for the religious scholars as part of the costs of the religious schools were provided by the Revenue from endowments. Until 1935, provision of eighty percent of the budget of religious schools and 30 percent of the school trustees was taken on by the Endowments[31]. This law of Reza Shah caused the financial resources of the discourse of Islamism to be calculated and limited. It was an issue which was at odds with the expansion of religious education that was recently accompanied by many changed by Ayatollah Hayeri.

\section{F-Unveiling and Opposition of Discourses}

For the definition of the society, discourses need to either accept the relations between people or change them. Indifference to the social relations by the dominant discourse is the beginning of popular resistance against that [32]. One of the interferences of Reza Shah in the social relations of people was the determination of the type covering. This interference which is known as the unveiling law is not accepted by people and the clergy. The reason for this resistance was the clergy's citations of and references to religious instructions according to which people can't oppose the laws of God.

The unveiling law that was legislated and enforced in 1936, 14 made evident the serious opposition and hostility between the modernist discourse of Reza Shah and the discourse of Islamism. From that time until the fall of Reza Shah in August1942, people, led by the clergy, were posed against Reza Shah. The constitutionalist discourse also, whose leaders were wither house-bound like SoleymanMirzaEskandari or were on exile like Taqizadeh or were killed like Ali Akbar Davar, could not restore themselves in August 1942. Thus, it is seen that with the failure of Reza Shah, the political chaos dominated Iran before the 1299 coup. The constitutionalist discourse in Majlis, the discourse of radical Islam in the society and the seminary and the monarchist discourse in the court took a stand against one another and this led to one decade of chaos and disorder in Iran.

\section{CONCLUSION}

The beginning of Reza Khan's rise to power, simultaneous with the need of the country of Iran and its political movements, aims to restore stability and security. In this historical period, the three constitutionalist, Islamist and monarchist discourses uphold the personal authority of Reza Shah for gaining power. Different reasons led to this support but what led to the accompaniment of the Islamist 
movement with Reza Khan and its change into a discourse was the need for order, the entry of foreign forces, opposition of the clergy with England in Iraq and also the collapse of the social order and the rise of anti-Shiite religious attitudes. Thus, the Islamist discourse supported Reza Shah and a kind of interaction took place between the discourses of Islamism and authoritarian modernization. This accompaniment in the two areas of the need of the Islamist discourse for security and the need of the discourse of modernization for legitimation, drew these two near to each other; but what led to the opposition and antagonism between these two discourses, was the involvement and legitimation of Reza Shah in the Islamist discourse. Determination of the topics of the religious courses, determination of the marriage laws, interference in endowments and legalization of the unveiling act brought about competition and antagonism between these two discourses. From the perspective of the analysis of Laclau and Mouffe, it could be said that Reza Shah's discourse, after stabilization, attempted to interfere in the area of the Islamist discourse in order to assume absolute power. As a result, due to the limitation of resources and antagonism of the demands, Islamism, by appealing to its mythological capacities, separated people from Reza Shah's state and led to his downfall.

\section{REFERENCES}

[1] Shirazi, A., the Political and Social Developments of Iran from the Qajar Period to the Rise of Reza Shah, Tehran: Ghomes, (2011).

[2] Rahmanian, D., the Challenge of the Republic and Monarchy and Rise of Reza Shah, Tehran: Markaz, (2001).

[3] Rajaei, Q., Islamophobia of Reza Shah, Tehran: Nashr-e Shahr, (2009).

[4] Safaei, E., National Foundations in the Municipality of Reza Shah the Great, Tehran: Bi-Na, (1974).

[5] Nowruzi, M., The Challenge of Religion and Democracy, Journal of Knowledge, N. 7,pp 24-49, (2002).

[6] McDaniel, D; (2002), an introduction to Discourse Theory, Trans. HosseinaliNozari, First Edition, Tehran: Discourse Culture Publication, p 10.

[7] Sultani, A., Power, Discourse and Language: The Mechanisms of Power in the Islamic Republic of Iran, First Edition, Tehran: Nashr-e Ney, p 25, (2006).

[8] eirahi, D., Power, Knowledge and Legitimation in Islam, Fourth Edition, Tehran: Nashr-e Ney, p 54, (2005).

[9] Ahmadi, B., The Structure and Interpretation of The Text, Vol.2, Tehran: Nashr-e- Markaz, p 388, (1992).

[10] Sultani, A., Power, Discourse and Language: The Mechanisms of Power in the Islamic Republic of Iran, First Edition, Tehran: Nashr-e Ney, p.26, (2006).

[11] Navayi, A., Iranian Governments from the Constitution to the Ultimatum, Tehran: Babak, p 134(1978).

[12] Ibid, p 243.

[13] Hosseinizadeh, M., Method and Theory in Political Sciences, Journal of Political Sciences, N. 28, p 246, (2004).

[14] Sultani, A., Discourse Theory, Journal of Political Sciences, N. 28, p 141, (2004)

[15] Hosseinizadeh, M., Political Islam in Iran, Qom: Mofid University, p 24, (2008).

[16] Cronin, S., The Making of Modern Iran: State and Society under Reza Shah, MortezaSaqebfar, Tehran: Jami, pp 64-70, (2004).

[17] Keddie,R, N., Qajar Iran and the Rise of Reza Khan 1796-1925, Trans. Mehdi Haqiqatkhah, Tehran: Contemporary History of Iran, p 166, (2006).

[18] Hosseinizadeh, M., Political Islam in Iran, Qom: Mofid University, p 315, (2008).

[19] Majd, M., From Qajar to Pahlavi, Trans. Reza Mirzani, MostafaAmiri, Tehran: Instituteof Political Studies and Research, pp 533-542, (2011).

[20] Jorgensen, M., Discourse Analysis as Theory and Method, Trans. HadiJalili, Tehran: Nashr-e Ney, p 45, (2013). 
[21] Bahar, M, a Concise History of the Political Parties; Qajar Extinction, Tehran: Rangin Print, p 48,(1945).

[22] Hosseinizadeh, M., Political Islam in Iran, Qom: Mofid University, p 32, (2008).

[23] Makki, H., a Twenty Year History of Iran, Vol. 7, Tehran: Amir Kabir Publications, p 68, (2000).

[24] Enayat, H., Six Articles on Religion and Society, Tehran: Moj-e Zaban, p 100, (1974).

[25] Sultani, A., Power, Discourse and Language: The Mechanisms of Power in the Islamic Republic of Iran, First Edition, Tehran: Nashr-e Ney, p 68, (2006).

[26] Ahmadvand, Z \&MontazerQaem, A (2015), Ayatollah Esfahani\& Reza Shah, p 2, Available on: http://www.ir-psri.com.

[27] Almoti, Z., Chapters from the Iranian History of Political and Social Struggles, Tehran: Chapakhsh Publications, p 64, (1992).

[28] Ibid, p 65.

[29] Jorgensen, M., Discourse Analysis as Theory and Method, Trans. HadiJalili, Tehran: Nashr-e Ney, p 127, (2013).

[30] Bashirieh, H., Political Sociology, Tehran: Nashr-e Ney, p 58, (1996).

[31] Azghandi, A., Iran's Foreign Relations 1942-1979, Tehran: Ghomes Publications, p 31, (1998).

[32] Van Dijk, T.A., Studies in Discourse Analysis: from Text Grammar to Critical Discourse Analysis, Group of Translators, Tehran: Center for Media Studies and Research, (2004). 